\title{
自家移植歯の根管充填状態と歯根膜治瘾との関係
}

\author{
濱本宜興 - 小林豊 - 濱本尚希 - 泉 健 次 \\ 小林正治·中島民雄·毛利環*·花田晃 治*
}

\section{Relationship between root canal filling and periodontal healing of autotransplanted teeth}

\author{
Yoshioki Hamamoto $\cdot$ Yutaka Kobayashi $\cdot$ Naoki Hamamoto $\cdot$ Kenji Izumi \\ Tadaharu Kobayashi $\cdot$ Tamio NaKaJima $\cdot$ Tamaki Mohri* Kooji Hanada*
}

\begin{abstract}
The relationship between root canal filling and the periodontal healing of autotransplantated teeth was studied clinically and radiographically in 21 autotransplanted teeth with complete root formation that were followed up for more than 6 months. The teeth were classified into three types according to the status of root canal filling immediately after transplantation: type A) teeth with root canal ( $\mathrm{s}$ ) wide enough to be detected on radiographs and root canal filling ( $\mathrm{s}$ ) to the apex (es); type $\mathrm{B}$ ) teeth having incomplete root canal filling ( $\mathrm{s}$ ) because of narrow root canal ( $\mathrm{s}$ ); and type $\mathrm{C}$ ) teeth having root canal ( $\mathrm{s}$ ) detectable on radiographs but with incomplete filling $(\mathrm{s})$. The periodontal healing was examined more than 6 months postoperatively. Ten teeth classified as type A had no clinical symptoms and showed regeneration of the periodontium on radiographs. Eight teeth classified as type B had no clinical symptoms but the periodontal spaces were indistinct in 5 teeth. No clinical symptoms were associated with 2 of 3 teeth classified as type C, but the periodontal spaces were not clearly seen in the apical regions. The presence of apical lesions and inflammatory resorption of the root was observed on radiographs of the other tooth. These findings suggest that periodontal healing is associated with the width of the root canal and the status of root canal filling.
\end{abstract}

Key words: autotransplantation (自家移植), tooth (歯), root canal filling (根管充填), periodontium (歯根膜), inflammatory root resorption (炎症性歯根吸収)

\section{緒言}

歯の自家移植に関する近年の基礎的および臨床的検 討の結果, 予後に重大な影響をおよほす置換性歯根吸

新潟大学歯学部口腔外科学第一講座

（主任 : 中島民雄教授）

*新潟大学歯学部歯科稪正学講座

(主任 : 花田晃治教授)

First Department of Oral and Maxillofacial Surgery, School of Dentistry, Niigata University (Chief: Prof. Tamio Nakajima)

*Department of Orthodontics, School of Dentistry, Niigata University (Chief: Prof. Kooji Hanada)

受付日: 平成 8 年 3 月 1 日
収と炎症性歯根吸収の発生原因の解明が進み，歯根の 完成度にかかわらず高い成功率を示すようになっ た1,2).

置換性歯根吸収は, セメント質の損傷によって引き 起こされる ${ }^{3,4)}$. われわれの移植歯歯根表面の肉眼的 性状と歯根膜治癒との関連についての研究においても, 歯根膜治癒に重要なのは歯根膜最内層の細胞とセメン 卜質の保全であることや, 通常の鉗子抜歯ではセメン 卜質に重大な損傷を与えることは少なく, 慎重に移植 歯を取り扱えば置換性歯根吸収は生じにくいことが明 らかになった ${ }^{5}$.

一方, 炎症性歯根吸収は歯髄壊死によって引き起こ されるが, 歯根完成歯を移植した場合ほとんどの症例 
表 1 対象患者の年齢, 性別, 移植歯, 移植部位, 観察期間

\begin{tabular}{|c|c|c|c|c|c|}
\hline 症 例 & 年 齢 & 性 別 & 移植歯 & 移植部位 & 観察期間 \\
\hline 1 & 28 & $\mathrm{M}$ & 81 & $\lcm{7}$ & 2 y $6 \mathrm{~m}$ \\
\hline 2 & 13 & $\mathrm{~F}$ & $\longdiv { 4 }$ & 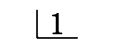 & 2 y $5 \mathrm{~m}$ \\
\hline 3 & 17 & $\mathrm{~F}$ & $\lcm{4}$ & $\lcm{7}$ & $1 \mathrm{y} 11 \mathrm{~m}$ \\
\hline 4 & 49 & M & 過剩歯 & 77 & 1 y $7 \mathrm{~m}$ \\
\hline 5 & 15 & $\mathrm{~F}$ & $\lfloor 1$ & $\bigsqcup$ & $1 \mathrm{y} 4 \mathrm{~m}$ \\
\hline 6 & 15 & M & 4 & $\lcm{2}$ & $6 \mathrm{~m}$ \\
\hline 7 & 17 & $\mathrm{~F}$ & $\lcm{4}$ & 7 & $1 \mathrm{y} 9 \mathrm{~m}$ \\
\hline 8 & 42 & $\mathrm{M}$ & 81 & 6 & $1 \mathrm{y} 6 \mathrm{~m}$ \\
\hline 9 & 14 & F & $\sqrt{7}$ & $\longdiv { 7 }$ & $6 \mathrm{~m}$ \\
\hline 10 & 40 & M & 87 & 7 & $6 \mathrm{~m}$ \\
\hline 11 & 42 & $\mathrm{~F}$ & $\longdiv { 8 }$ & $\sqrt{6}$ & 1 y $1 \mathrm{~m}$ \\
\hline 12 & 22 & $\mathrm{~F}$ & $\sqrt{8}$ & $\sqrt{6}$ & $1 \mathrm{y}$ \\
\hline 13 & 25 & $\mathrm{~F}$ & 81 & 77 & $7 \mathrm{~m}$ \\
\hline 14 & 43 & F & 81 & $\longdiv { 6 }$ & $2 y$ \\
\hline 15 & 28 & $\mathrm{~F}$ & 5 & $\longdiv { 6 }$ & $1 \mathrm{y} 1 \mathrm{~m}$ \\
\hline 16 & 34 & $\mathrm{~F}$ & 8 & 77 & $9 \mathrm{~m}$ \\
\hline 17 & 30 & M & 8 & $\longdiv { 6 }$ & $1 \mathrm{y}$ \\
\hline 18 & 23 & $\mathrm{M}$ & 81 & $\longdiv { 7 }$ & $7 \mathrm{~m}$ \\
\hline 19 & 18 & $\mathrm{~F}$ & 4 & $\longdiv { 6 }$ & $8 \mathrm{~m}$ \\
\hline 20 & 16 & $\mathrm{M}$ & 5 & $\sqrt{5}$ & $6 \mathrm{~m}$ \\
\hline 21 & $* 17$ & $\mathrm{~F}$ & 2 & 2 & 1 y $3 \mathrm{~m}$ \\
\hline
\end{tabular}

*術前根充症例. 移植後 1 年 3 か月目に根尖病巣が生じたが, その後再根充を行い, 1 年 7 か月後には臨床症状は消失し, 歯根吸収も停止した.

で 1 年以内に歯髄壊死が生じ, 放置すれば炎症性歯根 吸収を引き起こす 6〜8). したがって, 移植後は早期に 抜䯣を行い, 炎症性歯根吸収を予防しなければならな い2, 9, 10).この時の根管治療は, 根尖部まで緊密に根 管充填を行うのが望ましいが, 実際には歯根の湾曲, 狭窄，手技的な理由で, 理想的な根管充填が行えない 場合があり,それが術後経過に影響を与える可能性が ある. しかしながら根管充填の状態と術後経過との関 係を詳細に検討した報告はなく，術後経過の推測に困 る場合がある.そこで今回われわれは，根管の太さお よび根管充填の状態と, 歯根膜の再生との関係を, 臨 床的およびX 線学的に検討し, どの程度の根管充填 状態ならば臨床的に受け入れられるかを検討した。

\section{対象と方 法}

1992 年 9 月から 1995 年 4 月までの 2 年 8 か月間に, 新潟大学歯学部付属病院第一口腔外科にて歯の自家移 植を行なった症例のうち, 術中にセメント質の欠損， 損傷などの異常所見がなく, 6 か月以上の術後経過観 察を行い, 術後も明らかな置換性歯根吸収像が認めら れなかった 21 例を研究対象とした. 患者の平均年齢 は 26 歳, 最高年齢 49 歳, 最低年齢 13 歳, 性別は男性 8 例, 女性 13 例であった.

対象歯は全例, X 線写真上の根管孔直径が $1 \mathrm{~mm}$ 以 内の歯根完成歯で, 20 例では移植後に根管充填を行っ た.すなわち, 術後 3 週目に水酸化カルシウム製剤 （ビタペックス，ネオ製薬工業株式会社）による仮根充 を行い, その後, 歯冠修復の必要に応じて 3 か月以降 


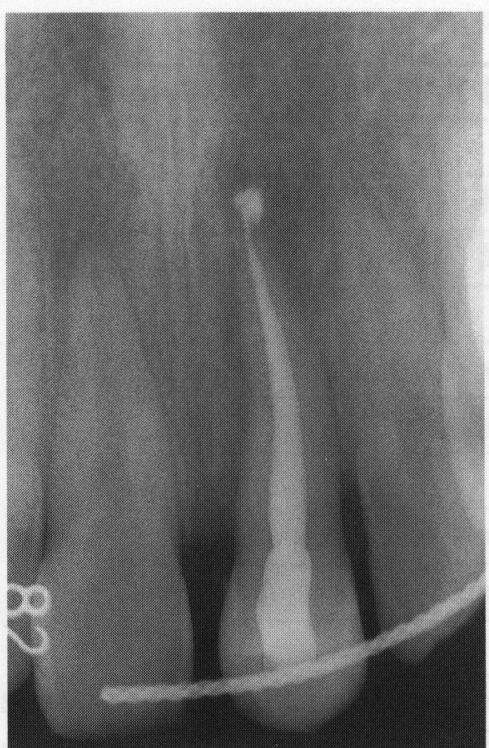

写真 $1 \mathrm{a}$ 右側下顎第一小臼歯の右側上顎中切歯部への 移植後 1 か月目のデンタル X 線写真. ビタペックスによ る仮根充は, 根尖孔より若干の漏出が認められるが根尖 部まで緊密に根充できている。

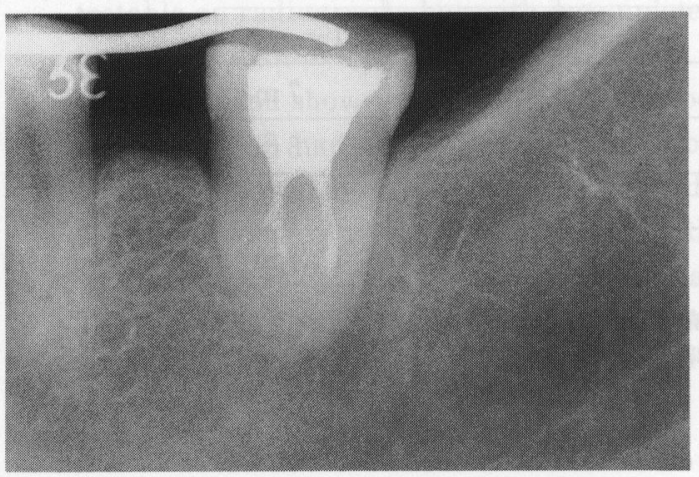

写真 $1 \mathrm{~b}$ 右側下顎智歯の左側下顎第二大臼歯部への移 植後 1 か月目のデンタル X 線写真. 根尖部の根管は狭窄 しており，X 線写真上では確認できず, 根充剤も根尖部 まで填入できていない.

にガタパーチャと根充用セメント（キャナルス）によ る本根充を行った. 残りの 1 例は移植前より根管充填 が行われており, 移植直後の再根管充填は行わなかっ た. 移植歯の種類は, 上下顎智歯が 10 例, 上下顎小臼 歯が 7 例, 上下顎前歯が 2 例, 下顎第二大鼠歯が 1 例, 過剩歯が 1 例であった. 移植部位は, 上下顎大臼歯部 が 16 例, 上顎前歯部が 4 例, 下顎小臼歯部が 1 例であっ た(表 1 ).

これら 21 症例を, 移植前または移植直後の $\mathrm{X}$ 線写

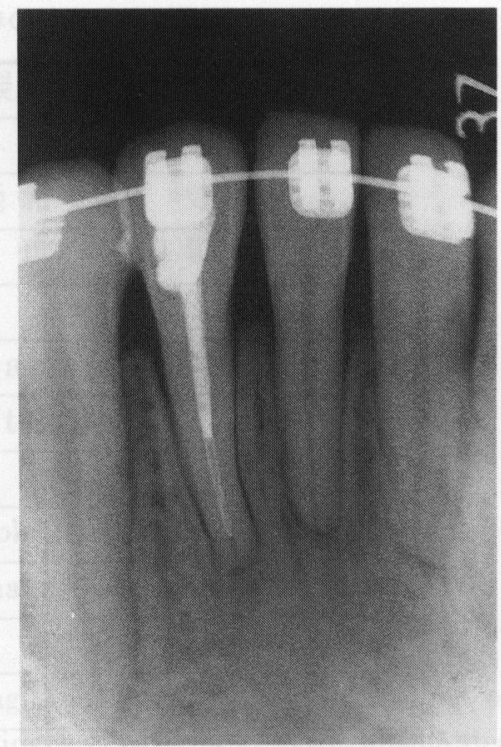

写真 $1 \mathrm{c}$ 術前根充が行われていた右側下顎側切歯の術前 デンタル X 線写真. 根尖部まで根管を確認できるにもか かわらず, 術前根充は不十分である.

真上の根管の太さと根管治療状態によって以下の 3 群 に分類した。

A）デンタル X 線写真上で確認できる程度の根管の 太さがあり，根尖まで緊密に根充されている（写真 $1 \mathrm{a}$ ).

B）根管の狭窄によってデンタル X 線写真上で根管 を確認できず, 根尖部まで根充されていない（写真 1 b).

C) デンタル X線写真上で確認できる程度の根管の 太さがあるが, 根尖まで緊密に根充されていない（写 真 $1 \mathrm{c})$.

また,これらの症例について以下の様な術後診査を おこなった。

・臨床的診査; ポケット深度, 動摇度, 打診音, 打診 痛または不快症状の有無.

$\cdot \mathrm{X}$ 線的診查 ; 移植後 6 か月以上経過した時点の X 線写真上での歯根膜再生状態を検討し以下の 3 群に分 類した.

1 ) 歯根のほほ全周にわたり歯根膜腔隙や歯槽硬線 が認められ, 歯根膜が再生していると考えられた（写 真 2 a).

2 ) 根充不良相当部の歯根膜腔隙が不明瞭で歯根膜 の再生が不良であると考えられた (写真 $2 \mathrm{~b}$ ).

3 ) 根充不良相当部の骨透過像や炎症性歯根吸収が 認められた (写真 $2 \mathrm{c}$ ).

結果

移植直後の X 線写真上での根管の太さと根管充填 


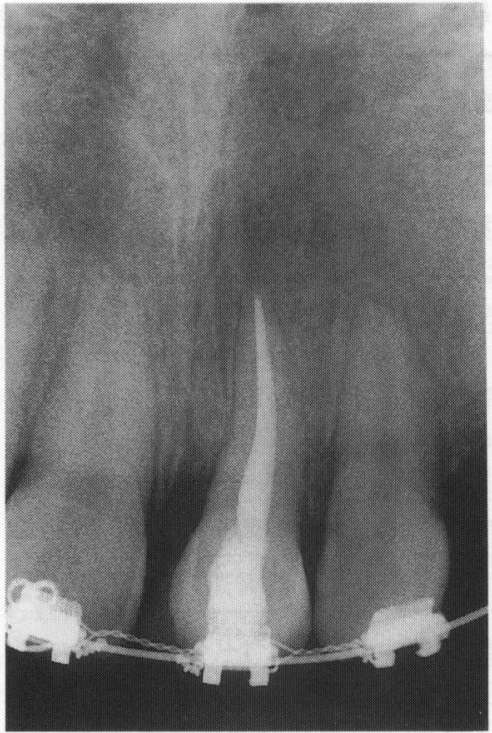

写真 $2 \mathrm{a}$ 写真 $1 \mathrm{a}$ の歯の移植後 1 年 5 か月目のデンタル $\mathrm{X}$ 線写真. 移植歯根尖孔は閉鎖しており, 歯根周囲には歯 根膜腔隙と歯槽硬線の形成が認められる。

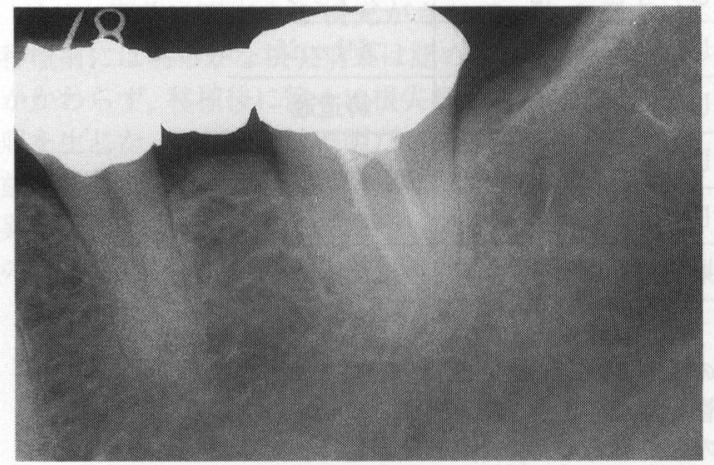

写真 $2 \mathrm{~b}$ 写真 $1 \mathrm{~b}$ の歯の移植後 2 年目の状態. 根尖部ま で根充できておらず, 根尖部の歯根膜は不明暸だが, 明ら かな歯根吸収が生じないまま経過している.

の状態から A）に分類されたのは 10 例で，年龄的には 比較的若い患者が多く, 移植歯は小臼歯が多かった (写真 $1 \mathrm{a}$ ). 臨床経過は全例でポケット深度は $2 \mathrm{~mm}$ 以下, 動摇度, 打診音は健全歯と同様であり, 打診痛 または打診による不快症状は無く, 臨床的に異常はな かった. 半年以降の $\mathrm{X}$ 線写真では 9 例で歯根膜腔隙の 再生が認められたが (写真 $2 \mathrm{a}$ )，1 例で根尖部の歯根 膜腔隙が若干不明瞭であった。

B）に分類されたのは 8 例で, 年齢は 20 歳代から 40 歳代と比較的高かった. 移植歯は上下顎智歯が多かっ

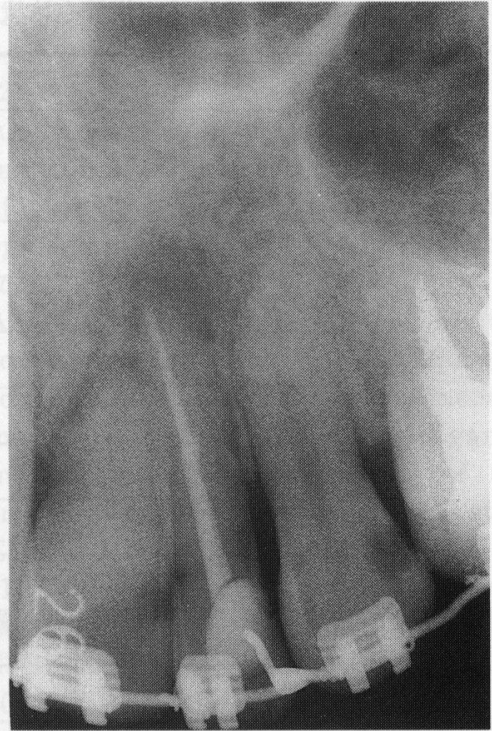

写真 $2 \mathrm{c}$ 写真 $1 \mathrm{c}$ の歯の右側上顎側切歯部への移植後 1 年 3 か月目のデンタル X 線写真. 術後 3 か月目頃から始 まった炎症性歯根吸収により根充が不十分な根尖部の歯 根は吸収されており, 骨透過像も認められる.

た (写真 $1 \mathrm{~b}$ ). 臨床経過は全例で異常なかったが, X 線写真では歯根膜腔隙の再生が認められた症例が 3 例, 根尖部歯根膜腔隙が不明暸な症例が 5 例であった（写 真 2 b).

C) に分類されたのは 3 例で, 年齢は全例 10 歳代で あった. 2 例で臨床経過には異常なかったが, X 線写 真では根尖部歯根膜腔隙が不明暸であった. 術前に行 われていた根充が不完全であったにもかかわらず, 移 植後に再根充を行わなかった 1 例では (写真 $1 \mathrm{c}$ ), 移 植後 1 年 3 か月を経て根尖病巣が生じた. X 線写真で は根尖部歯槽骨の透過像と, 根充がされていなかった 根尖部の歯根が吸収, 消失した（写真 $2 \mathrm{c}$ ）（表 2 ）.

臨床的およびX 線的経過と, 矯正治療, 鋳造冠, ブ リッジなどの術後治療内容との間には特徴的な関係は なかった（表 2 ).

$$
\text { 考察 }
$$

これまでの実験的および臨床的な研究によって，根 管孔直径が $1 \mathrm{~mm}$ 以内の歯根完成歯を移植した場合, その $55 \%$ の症例で 8 週間以内に, $86 \%$ の症例で 6 か月 以内に, $90 \%$ 以上の症例で 1 年以内に歯髄壊死が生じ, 放置すれば根尖病巣や炎症性歯根吸収などを引き起こ すことがわかっている ${ }^{6 \sim 8)}$. 炎症性歯根吸収は, 壊死 した歯髄由来の異物抗原が象牙細管内に存在し, なん らかの原因でその象牙質が露出したとき, 破骨細胞が 
表 2 根管充填状態㧍よび移植後の臨床経過, X 線的経過

\begin{tabular}{|c|c|c|c|c|}
\hline 症 例 & 根充状態 & 臨床経過 & X 線経過 & 術後治療 \\
\hline 1 & $\mathrm{~A}$ & 異常なし & 1 & 鋳造冠 \\
\hline 2 & A & 異常なし & 1 & 矯正治療中 \\
\hline 3 & A & 異常なし & 1 & 矯正治療中 \\
\hline 4 & $\mathrm{~A}$ & 異常なし & 1 & ブリッジ \\
\hline 5 & $\mathrm{~A}$ & 異常なし & 1 & 矯正治療中 \\
\hline 6 & A & 異常なし & 1 & 矯正治療中 \\
\hline 7 & A & 異常なし & 1 & 矯正治療中 \\
\hline 8 & A & 異常なし & 1 & 鋳造冠 \\
\hline 9 & A & 異常なし & 1 & 鋳造冠 \\
\hline 10 & $\mathrm{~A}$ & 異常なし & 2 & ブリッジ \\
\hline 11 & B & 異常なし & 1 & 鋳造冠 \\
\hline 12 & B & 異常なし & 1 & 鋳造冠 \\
\hline 13 & B & 異常なし & 1 & 鋳造冠 \\
\hline 14 & B & 異常なし & 2 & ブリッジ \\
\hline 15 & B & 異常なし & 2 & 矯正治療中 \\
\hline 16 & $\mathrm{~B}$ & 異常なし & 2 & ブリッジ \\
\hline 17 & B & 異常なし & 2 & ブリッジ \\
\hline 18 & B & 異常なし & 2 & 鋳造冠 \\
\hline 19 & $\mathrm{C}$ & 異常なし & 2 & 矯正治療中 \\
\hline 20 & $\mathrm{C}$ & 異常なし & 2 & 矯正治療中 \\
\hline 21 & $\mathrm{C}$ & 根尖病巣 & 3 & 矯正治療中 \\
\hline
\end{tabular}

・デンタル X 線写真上の根管充填状態 ;

A）デンタル X 線写真上で確認できる程度の根管の太さがあり，根尖まで緊密に根充されている.

B）根管の狭窄によってデンタル X 線写真上で根管を確認できず, 根尖部まで根充されていない.

C) デンタル X 線写真上で確認できる程度の根管の太さがあるが, 根尖まで緊密に根充されていない.

・臨床的経過 ; ポケット深度, 動摇度, 打診音, 打診痛または不快症状の有無.

- X 線学的経過 ;

1 ) 歯根のほほ全周にわたり歯根膜腔隙が認められる.

2 ) 根充不良相当部の歯根膜腔隙は不明瞭.

3 ) 根充不良相当部の骨の透過像または炎症性歯根吸収が認められる.

異物化した歯根を進行性に吸収することによって生じ ると考えられる ${ }^{1)}$. したがって, 移植後は早期に抜䯣 を行い, 異物化した歯䯣を除去すれば, 炎症性歯根吸 収を予防しうる $2,9,10)$.この時の根管治療は，壊死し た歯髄を完全に除去し, 根尖部まで緊密に根管充填を 行うのが望ましいのはいうまでもない. 今回の研究で も, 根尖部まで緊密に根管充填できた 10 症例では, 臨 床経過に異常なく, X 線的にも歯根膜の再生が確認で きた.一方, 若年者で, X 線的に確認可能な太い根管 を有しながら, 根管充填が不十分であった 3 症例では,
歯根膜腔隙が不明暸になったり, 根尖病巣や炎症性歯 根吸収が生じた.また, 20 歳代以降になると, 根管は 経年的に狭窄し, 根尖部では X 線的に根管を確認でき なくなり，また実際の根管治療でも根尖部まで十分に 拡大できない場合がある.さらに智歯では根管が湾曲 している事もあり, 理想的な根管治療が困難な場合が ある.このような 8 症例での歯根膜治痹状態は, 3 例 で歯根膜の再生が認められたが, 他の 5 例では根尖部 歯根膜腔隙が不明暸のままであった. 以上の所見より, $\mathrm{X}$ 線写真上での歯根膜治瘉状態に対する根管充填の 
影響は, 根管充填が不完全な部分の根管の太さに関係 しているのではないかと考えられた. 寸なわち，X 線 的に根管が確認できる程度の太い根管では異物量も多 く, 骨不透過像や炎症性歯根吸収が生じるが, X 線的 に根管が確認できない狭窄した根管では，根管内に残 存する壊死歯髄の量も少なく, 部分的に歯根膜再生が 不完全になる程度の影響しかないと考えられた。

臨床的には骨不透過像や炎症性歯根吸収が生じた症 例は, 根尖部歯肉の発赤, 腫脹, 打診音の鈍化, 違和感 などの根尖性歯周炎症状を示すので, 再根管治療が必 要と考えられた。一方, 歯根膜腔隙が不明瞭な程度の 異常では, 臨床症状はなく, その変化は 1 年以上経過 した症例でも不変であり, 恐らく今後も急速な歯根吸 収を生じることなく推移し, 臨床的にも実用上問題な いと考えられた。

歯根完成歯の根管治療として, 当科では移植後 3 週 目に失活抜䯣, 水酸化カルシウム製剤による仮根充を 行い，3か月以降に歯根膜治癒を確認したのち，ガ夕 パーチャによる本根充を行うことにしている. 水酸化 カルシウム製剤は殺菌作用があり,また象牙細管内を 浸透し, 歯根表面の破骨細胞にも影響を及ほすことに よって歯根吸収を抑制する可能性も指摘されてお $\eta^{11)}$, 移植直後の仮根充材として優れている ${ }^{12)}$.

なお, 術前に不完全な根充がされていた 1 例では, 移植前には明らかな根尖病巣は認められなかったにも かかわらず, 移植後に徐々に根尖病巣と炎症性歯根吸 収を生じた。この理由は不明だが, 移植に伴う表面性 歯根吸収などによるセメント質の障害が, 象牙管内の 異物抗原を歯根表面に漏出させ, 破骨細胞を誘導した のかもしれない.

\section{結語}

1. X 線写真上での歯根膜治癒に対する根管充填の 影響は, 根管充填が不完全な部分の根管の太さに関係 しているのではないかと考えられた。

2. X 線写真上で確認できない程度にまで狭窄した 根管では, 根管充填が不十分でも, 臨床的には問題が なかった。

3.X 線写真上で確認できる程度の太さの根管では, 根管充填が不十分な場合, 歯根吸収や根尖病巣を生じ る可能性があるので, 再根充が必要である.

\section{引用 文 献}

1) Andreasen, J.O.: Atlas of replantation and transplantation of teeth. 1 st Ed, Mediglobe, Fribourg, Switzerland, 1992, p15-56.

2) Tsukihoshi, M.: Autogenous tooth trans- plantation: A reevaluation. Int. J. Periodontics and Restorative Dentistry. 13: 121-149 1993.

3) Andreasen, J.O.: Relationship between cell damage in the periodontal ligament after replantation and subsequent development of root resorption. Acta odont scand. 39: 15-25 1981.

4) Andreasen, J.O.: Review of root resorption systems and models. Etiology of root resorption and the homeostatic mechanisms of the periodontal ligament. In the biological mechanisms of tooth eruption and root resorption. 1 st $\mathrm{Ed}$, EBSCO Media, Birminggham, 1988, p 9 21.

5）濱本宜興, 中島民雄, 他 : 移植歯歯根表面の肉 眼的性状と臨床的経過に関する研究. 日口外誌 40: 1222-1227 1994.

6) Andreasen, J.O., Paulsen, H.U., et al.: A long term study of 370 autotransplanted premolars. Part II . Tooth survival and pulp healing subsequent to transplantation. European J. Orthodontics. 12: 14-24 1990.

7) Andreasen, J.O., Paulsen, H.U., et al.: A long-term study of 370 autotransplanted premolars. Part III. Periodontal healing subsequent to transplantation. European J. Orthodontics. 12: 25-37 1990.

8) Kristerson, L.: Autotransplantation of human premolars. A clinical and radiographic study of 100 teeth. Int. J. Oral Surg. 14: 200-221 1985.

9) Andreasen, J.O.: Atlas of replantation and transplantation of teeth. $1 \mathrm{st} \mathrm{Ed}$, Mediglobe, Fribourg, Switzerland, 1992, p57-98.

10) Cvek, M.: Treatment of non-vital permanent incisors with calcium hydroxide. II . Effect on external root resorption in luxated teeth compared with effect of root filling with guttapercha. A follow-up. Odont. Revy. 24: 343-354 1973.

11）大出祥幸, 白瀬敏臣,他：外傷歯における水酸 化カルシウムの役割. ザ クインテッセンス 14: 303-317 1995.

12) Cvek, M., Granath, L.E.: Treatment of non-vital permanent incisors with calcium hydroxide. III. Variation of occurrence of ankylosis of reimplanted teeth with duration of extra-alveolar period and storage environment. Odont. Revy. 25: 43-56 1974. 